Oral Presentation and Publication for

1998 International Symposium on Corrosion in the Pulp and Paper Industry,

Ottawa, Ontario, Canada, May 26-29, 1998

$$
\text { CONF-980555-- }
$$

\title{
FATIGUE CRACKING OF COEXTRUDED 304L/CS TUBES*
}

R. W. Swindeman, J. R. Keiser, and P. J. Maziasz

\author{
Metals and Ceramics Division \\ OAK RIDGE NATIONAL LABORATORY
}

P.O. BOX 2008

Oak Ridge, TN 37831-6155

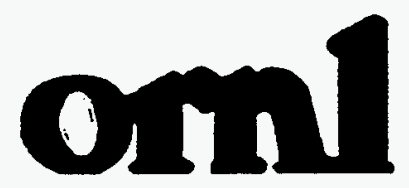

DISTRIBUTION OF THIS DOCLMENT IS UNLIMITED

REOEMED

MYO 61998

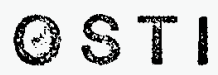

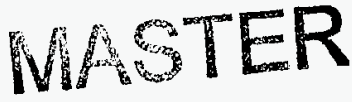

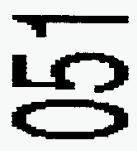

*Research sponsored by the U.S. Department of Energy, Assistant Secretary for Energy Efficiency and Renewable Energy, Office of Industrial Technologies, Advanced Industrial Materials Program, under Contract DE-AC05-960R22464 with Lockheed Martin Energy Research Corp.

The submitted manuscript has been authored by a contractor of the U.S. Government under contract No. DE-AC05-960R22464. Accordingly, the U.S. Govemment retains a nonexclusive, royalty-free license to publish or reproduce the published form of this contribution, or allow olhers to do so, for U.S. Government purposes. 


\section{DISCLAIMER}

This report was prepared as an account of work sponsored by an agency of the United States Government. Neither the United States Government nor any agency thereof, nor any of their employees, makes any warranty, express or implied, or assumes any legal liability or responsibility for the accuracy, completeness, or usefulness of any information, apparatus, product, or process disclosed, or represents that its use would not infringe privately owned rights. Reference herein to any specific commercial product, process, or service by trade name, trademark, manufacturer, or otherwise does not necessarily constitute or imply its endorsement, recommendation, or favoring by the United States Government or any agency thereof. The views and opinions of authors expressed herein do not necessarily state or reflect those of the United States Government or any agency thereof. 
FATIGUE CRACKING OF COEXTRUDED 304L/CS TUBES

\author{
R. W. Swindeman, J. R. Keiser, and \\ P. J. Maziasz \\ Oak Ridge National Laboratory, Oak Ridge TN 37831-6155
}

\section{L. Singbeil}

Pulp and Paper Research Institute of Canada Vancouver, British Columbia

\section{ABSTRACT}

The mechanical and thermal fatigue of austenitic stainless steels was examined for the maximum temperature range expected in coextruded floor tubes of recovery boilers to determine the likelihood that the cracking in the $304 \mathrm{~L}$ stainless steel cladding could be fatigue related. The microstructures and cracking patterns of fatigue-tested specimens were compared to features observed in cracked cladding and significant differences were found which suggested that fatigue was not the most likely cause for failure. Biaxial thermal fatigue testing of coextruded tubes and panels was performed to gather more evidence of cracking patterns. Here, transient thermal stresses were imposed by rapidly heating the tubing surface with lamps. In spite of high surface temperatures, no cracks were produced in the $304 \mathrm{~L}$ stainless steel cladding, and this observation was interpreted as evidence that cracking must be corrosion related.

\section{INTRODUCTION}

The evaluations described here are part of a multidisciplinary research program to evaluate materials for improved performance of black liquor recovery boilers. One problem being addressed in this program is cracking in the stainless steel cladding of coextruded floor tubes [1]. At issue is whether the cracking is caused by thermal fatigue, corrosion, or a combination of the two mechanisms [2]. This paper summarizes efforts to determine if the cracking could be due to thermal fatigue. The effort includes a review of fatigue data related to the composite tube materials, experimental work on fatigue of materials, tubes, and panels, and evaluations of fatigue-induced microstructures and cracking patterns.

\section{REVIEW OF FATIGUE}

Boilers in the United States are designed to meet the construction requirements of the ASME Boiler and Pressure Code Section I on Power Boilers. In this code there are no specific requirements for fatigue design, but the designer is cautioned to consider such loadings if they are judged to be important to safe operation. The possibility of thermal fatigue in composite tubes in black liquor recovery boilers was recognized in the early seventies by Egnell and Tornblom [3]. In an experimental program, composite tubes with and without notches were thermally cycled between 200 and $500^{\circ} \mathrm{C}$ and 200 and $700^{\circ} \mathrm{C}$. Tubes cycled between 200 and $500^{\circ} \mathrm{C}$ survived 10,000 cycles without cracking. A stress analysis was performed and the results were used to estimate fatigue life from procedures recommended in ASME Section III Code Case 1331-5. Life beyond 10,000 hours was estimated, which was in agreement with experimental data. Cycling to the higher temperature $\left(700^{\circ} \mathrm{C}\right)$ was found to reduce life. New experimental studies were undertaken in the 1990s which involved cycling to $600^{\circ} \mathrm{C}$ or higher [4-6]. Several methods were used for introducing cyclic strain, and these methods included thermal shocking of tubes, and restrained thermal and isothermal cycling of specimens representative of cladding materials. In most instances relatively high cyclic strains or high cyclic temperatures were needed to induce fatigue cracks. Microstructural studies of cracked cladding tubes were also performed recently, and these studies suggested that exposed tubing did not reach the exposure temperatures and times needed to produce fatigue failures [7].

The thermal fatigue data collected during this review were compared to the ASME Sect. III, Subsect. NH design curve for 300 series stainless steels [8-12]. The code curve is based on isothermal fatigue data, while the data complied in the thermal fatigue collection included fully restrained thermal fatigue data and thermal-mechanical fatigue data (which were produced under conditions of mechanical fatigue under changing temperature). As shown in Fig. 1, all thermal fatigue data fell near or above the design curve for $427^{\circ} \mathrm{C}$, regardless of the peak temperature in the cycle. Thus, a floor tube designed for fatigue at $427^{\circ} \mathrm{C}$ maximum temperature should have some margin on life, even if the temperature excursions exceeded $427^{\circ} \mathrm{C}$. The design curves for temperatures above $427^{\circ} \mathrm{C}$ move to the left and below the curve for $427^{\circ} \mathrm{C}$.

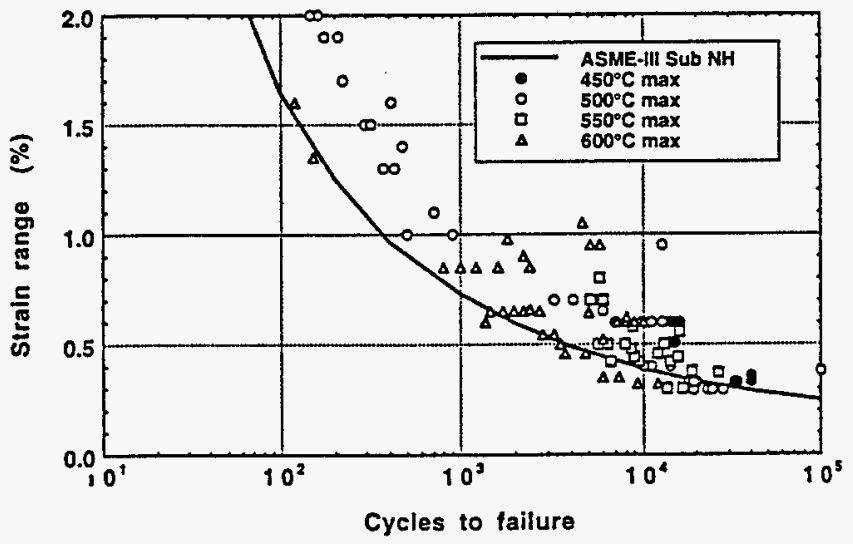

Fig. 1. Comparison of thermal fatigue data to the ASME design curve for $427^{\circ} \mathrm{C}$.

\section{EXPERIMENTAL TESTING}

A few exploratory fatigue tests were performed on simulated cladding. Type $304 \mathrm{~L}$ stainless steel plate $(25-\mathrm{mm}$ thick) was cold rolled to $50 \%$ reduction of thickness and annealed at $900^{\circ} \mathrm{C}$ for 0.5 hour. The resulting grain size was fine (ASTM grain size number 8 ) and typical of the grain size 
in the coextruded tubes. The room temperature tensile yield was found to be near $300 \mathrm{MPa}$. Fatigue specimens were machined from the plate and tested under isothermal and thermal fatigue conditions using techniques conforming to ASTM E 606. Isothermal fatigue tests were performed at 300 and $600^{\circ} \mathrm{C}$, with and without tensile hold time at the peak temperature, and strain range values below $1 \%$. The material exhibited fatigue behavior typical of the data base on which the ASME code curves were developed. An additional fatigue test at $600^{\circ} \mathrm{C}$ with a 0.1 hour hold time was performed on a specimen from the cold rolled plate. Although much stronger, the fatigue life of the cold worked material (CW 304L) was the same as the annealed specimen (FG 304L), as shown in Fig. 2. Two thermal mechanical fatigue tests were performed. In one case, the specimen was fully restrained during the cycle from 300 to $600^{\circ} \mathrm{C}$. The specimen was cycled until the stress range was stabilized (200 cycles), then the test was stopped and the specimen examined metallurgically. In the other case, a mechanical strain was imposed as the specimen cycled between 300 and $450^{\circ} \mathrm{C}$. The test at $0.6 \%$ mechanical strain range was discontinued at 3600 cycles, which was near the expected life.

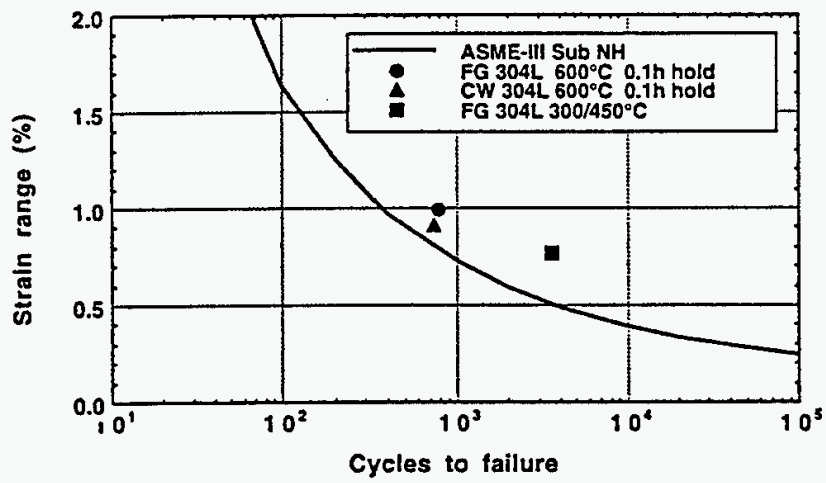

Fig. 2. Comparison of fatigue data for 304LSS simulated cladding with the ASME design curve for $427^{\circ} \mathrm{C}$.

Two cyclic experiments were performed on composite tubes. In each, a $14.5 \mathrm{KW}$ lamp heater was used to rapidly heat the surface of the tube from 215 to $610^{\circ} \mathrm{C}$. The inside of the tube was air cooled. Typically, the upward transient was accomplished in three minutes and cooling occurred over 12 minutes, including a hold to establish a uniform temperature profile at the lower temperature. Measurement of temperatures during the transient indicated through wall temperature gradients of $30^{\circ} \mathrm{C}$ maximum. The temperature differences were judged to be inadequate to produce fatigue failure, so the test was discontinued after several hundred cycles. A second test was performed in which a tube was heated on one side only, cycling between 250 and $450^{\circ} \mathrm{C}$. The maximum temperature difference from the hot side to the cooler side of the tube was near $130^{\circ} \mathrm{C}$. Several hundred cycles were introduced, but no change in hardness or cracking of the tube surface was observed. A thermal transient test on a five-tube panel was also performed. Here, the center tube was heated on one side by a $7.5 \mathrm{KW}$ lamp heater $\left(750 \mathrm{KW} / \mathrm{m}^{2}\right)$ while the inside of the tube was air cooled and the two outer tubes (1st and 5th) were water cooled. The crown of the center tube was cycled between 250 and $540^{\circ} \mathrm{C}$ with heating time less than two minutes. The temperature of the back side of the center tube cycled between 140 and $170^{\circ} \mathrm{C}$. A strain gage located on the back side indicated a permanent change in the first cycle and no change thereafter. The panel was subjected to 1000 cycles and inspected visually. No cracking was observed.

\section{METALLURGICAL EXAMINATIONS}

Optical and transmission electron microscopy were used to examine cracking patterns and substructure. The cracks produced by fatigue testing were surface initiated, transgranular, and exhibited branching or forking that was limited to within a few grains from the main crack, as shown in Figs. 3 and 4. Further, the cracks did not appear to follow crystallographic orientations on the scale at which they were observed. By contrast, cracks in cladding often exhibited considerable branching. All were transgranular and often showed preferences toward crystallographic planes, as shown in Fig. 5.

The substructure was examined by transmission electron microscopy (TEM) in both the fatigue-tested specimens and the service-exposed cladding. In all cases, the substructure consisted of arrays of dislocations on slip bands and a moderate density of tangles, loops, and dipoles in the regions between the slip bands. The substructures were similar to those observed by Makipaa, et al. [7]. No well-defined dislocation cells or subgrains, typical of isothermal fatigue, were found in any of the foils that were investigated [13]. The substructures in a thermal-mechanical fatigued specimen and the cladding are compared to the cladding in Fig. 6.

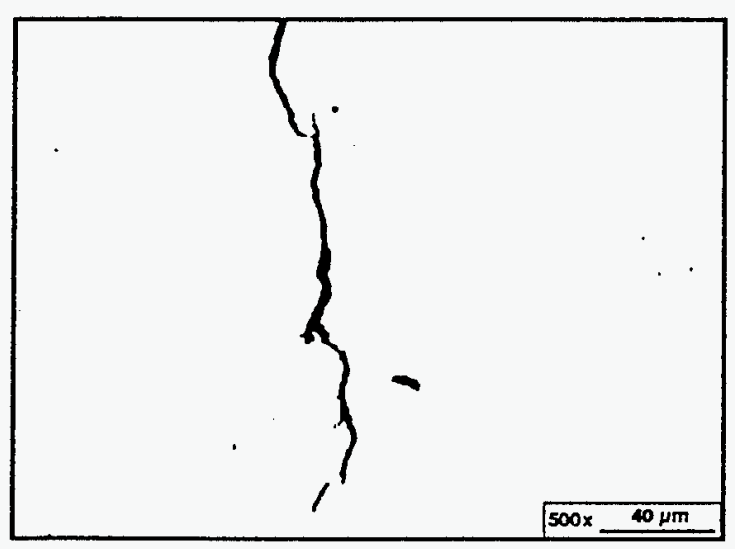

Fig. 3. Fatigue cracks produced in simulated 304L SS cladding by isothermal fatigue $\left(600^{\circ} \mathrm{C}\right.$ with $0.1 \mathrm{~h}$ hold).

The interface between the cladding and the base metal was investigated for metallurgical evidence of thermal excursions to temperatures high enough to produce thermal fatigue damage. Pieces of clad tubing were aged at temperatures in the range of 450 to $600^{\circ} \mathrm{C}$ for 1 to $500 \mathrm{~h}$. Metallurgical samples were prepared, and the interface was examined for metallurgical changes. It was found that precipitation could be detected for exposures as short as 18 hours at $545^{\circ} \mathrm{C}$. The precipitates 
- - were observed along the interface after etching with Nital (Fig. 7). Such precipitates were also detected after 24 hours aging at $480^{\circ} \mathrm{C}$. Similar precipitates were not observed in the cladding of cracked tubes, as indicated in Fig. 8.

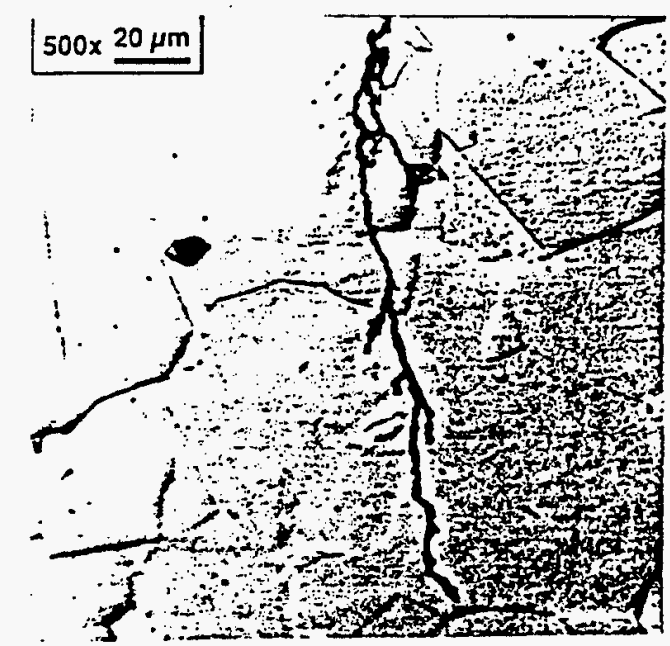

Fig. 4. Fatigue cracks produced in simulated $304 \mathrm{~L}$ SS cladding thermal-mechanical fatigue $\left(300\right.$ to $450^{\circ} \mathrm{C}$ for 3600 cycles).

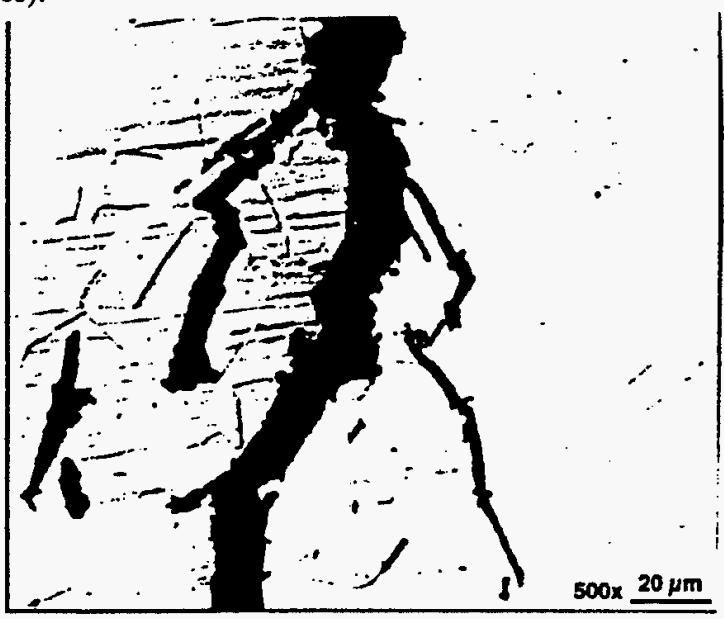

Fig. 5. Typical cracks observed in 304L SS cladding.

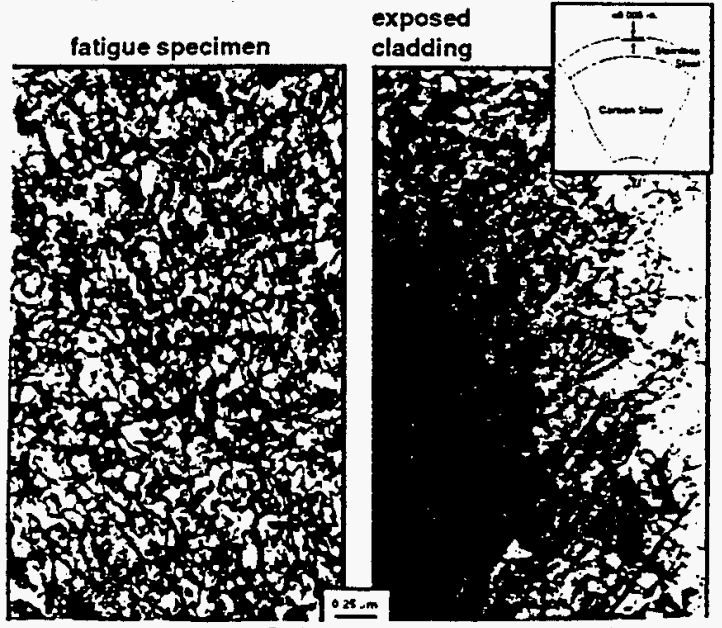

Fig. 6. Comparison of the TEM-observed substructure in a fatigue tested specimen ( 300 to $600^{\circ} \mathrm{C}$ for 200 cycles) with the exposed cladding.
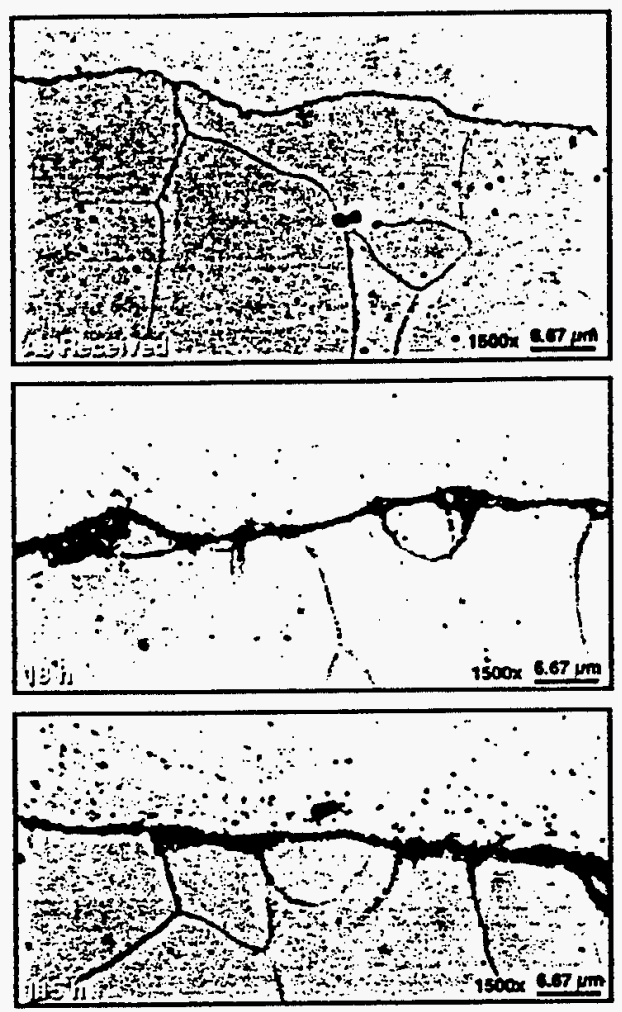

Fig. 7. Photomicrographs of the clad/base metal interface aged at $545^{\circ} \mathrm{C}$. Nital etchant.

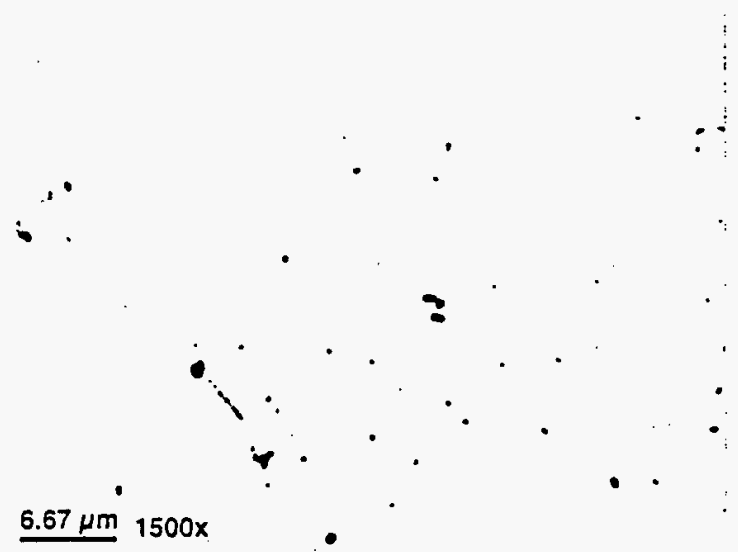

Fig. 8. Photomicrographs of the clad/base metal interface of a cracked boiler tube. Nital etchant.

\section{DISCUSSION}

The fatigue data for stainless steels provided in Fig. 1 may be used as a reference for assessing the likelihood that the cracking of composite tubes is due to thermal fatigue. If the thermal fatigue results from an upward temperature transient that heats the cladding to $540^{\circ} \mathrm{C}$ and the cooler base metal and surrounding tubes fully restrain the cladding, then the maximum strain that the cladding could experienced is in the vicinity of $0.5 \%$. The stress range corresponding to this strain range exceeds $500 \mathrm{MPa}$. For fatigue to occur, the same local 
region of the floor would have to experience this transient 10,000 times or more. If the transient temperature only reaches $450^{\circ} \mathrm{C}$ and the cladding is not fully restrained, cyclic strains could be at the yield limit, say $0.25 \%$. At this lower strain range the cladding could tolerate 100,000 cycles or more. An analysis of a hot-spot transient was performed by Taljat et al. [14]. For tube crown temperatures reaching $540^{\circ} \mathrm{C}$, they predicted yielding of the cladding, but the stress range was less than $500 \mathrm{MPa}$. In producing fatigue failure, the 10,000 or more transients to $540^{\circ} \mathrm{C}$ would accumulate significant time at this temperature. Precipitation would occur at the clad/base metal interface, as indicated in this investigation and that of Makipaa, et al. [7]. In Fig. 7, it is seen that no such precipitation has occurred. If the transient reached $600^{\circ} \mathrm{C}$, full restraint would produce a strain range in excess of $0.65 \%$ and life could be reduced to 2000 cycles or fewer, as indicated by the data in Fig. 1. Again, there would be some metallurgical evidence of such a high temperature exposure. Failure analysis of some floor tubes and corner tubes have shown evidence of very high temperatures. Often, the cracks in the cladding continue into the carbon steel. Such behavior might be expected if fatigue conditions controlled failure. The fact the many tubes fail without evidence of fatigue cracks penetrating into the base metal suggests that other mechanisms may be operative. Transients occur, however, and these could produce a redistribution of stresses that promote cracking at temperatures where an aqueous environments exist and conditions favor stress corrosion cracking. Transients also play a role in promoting high-temperature crack propagation. The hot-spot panel testing described above is being evaluated by X-ray diffraction and hardness testing. If it is determined that significant strain cycling has occurred, the thermal cycling will continue.

\section{SUMMARY}

Mechanical and thermal cycling tests were performed on 304L stainless steel to produce data needed to assess the likelihood that the cracking of recovery boiler floor tubes is due to thermal fatigue alone. No conclusive evidence was found to support this view.

\section{ACKNOWLEDGMENTS}

This research was sponsored by the U.S. Department of Energy, Assistant Secretary for Energy Efficiency and Renewable Energy, Office of Industrial Technologies, Advanced Industrial Materials Program, under contract DEAC05-960R22464 with Lockheed Martin Energy Research Corporation.

\section{REFERENCES}

1. Keiser, J. R., et al., "Analysis of Composite Tube Cracking in Recovery Boiler Floors", Proceedings of TAPPI Engineering Conference, Nashville, TN, 1997.
2. Singbeil, D. L., et al., Composite Tube Cracking in Kraft Recovery Boilers: A State-of-the-Art Review, ORNL/TM-13442, Oak Ridge National Laboratory, Oak Ridge, TN, July, 1997.

3. Egnell, L. and Tornblom, H., "Thermal Fatigue in Composite Tubes", paper C238/73 in Joint International Conference on Creep and Fatigue in Elevated Temperature Applications, Institute of Mechanical Engineers, London, UK, 1973.

4. Linde, L. And Henderson, P. J., "Thermal Mechanical Fatigue of a Composite Steel," International Symposium on Fatigue under Thermal and Mechanical Loading, Petten, Netherlands, May 22, 1995.

5. Noble, J., et al., Sanicro 38/4L7 - A New Composite Tube for BLRB Floors, S-54-28-ENG, Sandvik AB, Sanviken, Sweden, 1995.

6. Wilson, A., Summary of Thermal Fatigue and Low Cycle Fatigue Conceming Composite Tubes Combinations, T9500037, Sandvik AB, Sanviken, Sweden, January, 1995.

7. Makipaa, M., et al., "Studies with TEM, SEM, and Optical Microscope on the Cracking of BLRB Composite Floor Tubes", 8th International Symposium on Corrosion in the Pulp and Paper Industry, Swedish Corrosion nstitute, Stockholm, Sweden, 189-197, 1995.

8. Swindeman, R. W., Fatigue of Austenitic Stainless Steels in the Low and Intermediate Cycle Range, ORNL-TM1363, Oak Ridge National Laboratory, Oak Ridge, TN, 1966.

9. Kuwabara, K. and Nitta, A, "Effect of Strain Hold-Time of High Temperature on Thermal Fatigue Behavior of Type 304 Stainless Steel," pp. 161-177 in 1976 ASME-MPC Symposium on Creep-Fatigue Interaction, MPC-3, ASME, New York, NY, 1976.

10.Hayashi, M., "Thermal Fatigue Behavior of Type 304 Stainless Steel in Simulated BWR Environment," pp. 71 to 78 in Fatigue and Crack Growth Environmental Effects, Modeling Studies, and Design Considerations, PVP-Vol. 306, ASME, New York, NY, 1995.

11.Majumdar, S, "Thermomechanical Fatigue of Type 304 Stainless Steel," pp. 31-36 in Thermal Stress, Material Deformation, and Thermo-Mechanical Fatigue, PVP-Vol. 123, ASME, New York, NY, 1987.

12.Corum, J. M., Gwaltney, R. C., and Sartory, W. K, Assessment of Adequacy of High-Temperature Design Methodology Based on U.S. and U.K. Thermal Shock Tests, ORNL-6235, Oak Ridge National Laboratory, Oak Ridge, TN, March 1986.

13.Zauter, R., Christ, H.-J., and Mughrabi, H., "Some Aspects of Thermomechanical Fatigue of AISI 304L Stainless Steel: Part II. Dislocation Arrangements", Metall. Trans. A. 25A J407-413 (1994).

14. Taljat, B., et al., "Mechanical Design of Steel Tubing for Use in Black Liquor Recovery Boilers', paper submitted to 9th International Symposium on Corrosion in the Pulp and Paper Industry, Ottawa, Ontario, May 26-29, 1998. 


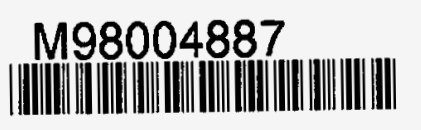

Report Number (14) ORNL/CP--97557
CONF-980555--

Publ. Date (11) $\frac{199803}{\text { Sponsor Code (18) }}$
UC Category (19)
UC-900, DOE/ER 